\title{
Makna Konotasi Rebranding Logo TVRI
}

\author{
Sumbo Tinarbuko \\ Prodi Desain Komunikasi Visual, Jurusan Desain, \\ Fakultas Seni Rupa dan Program Pascasarjana ISI Yogyakarta \\ Jalan Parangtritis KM. 6,5 Sewon Bantul, Daerah Istimewa Yogyakarta
}

sumbotinarbuko@gmail.com

Tulisan ini dibuat guna memahami makna konotasi pada tanda serta pesan komunikasi visual yang terkandung dalam rebranding logo TVRI. Bagi desainer komunikasi visual, mempelajari dan memanfaatkan semiotika komunikasi visual untuk memahami tanda verbal dan tanda visual serta makna konotasi rebranding logo TVRI menjadi sangat penting. Hal penting lainnya, desainer komunikasi visual sebagai produsen tanda akan lebih kreatif dalam menciptakan tanda verbal dan tanda visual serta pesan verbal dan pesan visual. Tulisan ini dibuat menggunakan metode penelitian kualitatif dengan mendeskripsikan dan menginterpretasikan makna konotasi rebranding logo TVRI berdasarkan bangunan teori semiotika, teori desain komunikasi visual dan teori branding. Metode analisis semiotika komunikasi visual ditawarkan dan digunakan sebagai metode analisis tanda dan pesan komunikasi visual rebranding logo TVRI. Prosesnya dilakukan dengan memanfaatkan analisis Triadik Sumbo Tinarbuko. Konsep analisis Triadik Sumbo Tinarbuko penulis ciptakan untuk mengidentifikasikan, mendeskripsikan dan memahami makna konotasi tanda verbal dan tanda visual serta pesan verbal dan pesan visual yang terkandung dalam rebranding logo TVRI.

Kata kunci: rebranding, logo TVRI, semiotika.

\section{The Connotation Meaning of TVRI Logo Rebranding}

This paper was written to understand the connotations meaning of signs and visual communication messages contained in the TVRI logo rebranding. For visual communication designers, learning and utilizing the semiotics of visual communication to understand verbal signs, visual signs, and the connotation meaning of the TVRI logo rebranding are very important. Another important thing, visual communication designers as sign producers will be more creative in creating verbal signs and visual signs as well as verbal and visual messages. This paper was written using qualitative research methods by describing and interpreting the connotation meaning of the TVRI logo rebranding based on the semiotics theory, visual communication design theory, and branding theory. The semiotics of visual communication analysis method is offered and used as an analysis method of signs and visual communication messages of TVRI logo rebranding. The process is utilizing the Triadic of Sumbo Tinarbuko analysis. The concept of Triadic of Sumbo Tinarbuko created by the author to identify, describe, and understand the connotation meaning of the verbal and visual signs as well as verbal and visual messages contained in the TVRI logo rebranding.

Keyword: rebranding, TVRI logo, semiotics.

Proses Review : 1 - 28 Januari 2020, Dinyatakan Lolos: 10 Februari 2020 


\section{PENDAHULUAN}

Direktur Utama TVRI Helmy Yahya kepada pers seperti dikutip harian Media Indonesia (30/3/2019) mengatakan, peluncuran logo baru TVRI berlangsung pada Jumat (29/3/2019) malam di Auditorium TVRI, Senayan, Jakarta. Momentum peluncuran logo baru TVRI Pusat juga diikuti 29 stasiun lokal TVRI di 29 kota. 'Logo baru ini menjadi darah segar dan semangat baru TVRI. Logo baru TVRI yang menonjolkan huruf kapital RI ini lebih simpel, mencerminkan Indonesia bagian dari dunia serta budaya Indonesia juga budaya dunia," ungkap Helmy Yahya.

Orang nomor satu di TVRI itu kemudian mengajak siapa pun untuk mencintai TVRI. 'Marilah kita cintai TVRI sebagi milik masyarakat Indonesia. TVRI juga berkomitmen melestarikan budaya Indonesia demi peradaban dunia," ajak Helmy Yahya.

Sementara itu, Kepala Stasiun TVRI Jogja Tri Widiarto kepada wartawan Harianjogja.com (2/4/2019) Herlambang Jati Kusumo mengatakan, ''Logo baru TVRI pada 2019 semakin memicu TVRI Jogja untuk selalu memberikan konten yang terbaik bagi masyarakat dan menjadi pengungkit untuk bersaing di tingkat internasional.

Bagi Kepala Stasiun TVRI Yogyakarta, keberadaan logo baru, selain menyampaikan TVRI sebagai pemersatu bangsa juga sebagai langkah TVRI siap menuju kancah dunia. Di samping itu, paparnya, pergantian logo TVRI diharapkan mampu mengubah budaya organisasi dan budaya kerja menjadi semakin baik. "'Hal itu perlu diupayakan agar lebih menarik teman-teman generasi milenial. Di sisi lainnya, wajib dilakukan guna menggaet kaum milenial. Untuk mendekatkan diri kepada generasi milenial, saat ini TVRI Jogja telah gencar berbagi program lewat media sosial," papar Kepala Stasiun TVRI Jogja Tri Widiarto.

Keinginan dan harapan Direktur Utama TVRI Helmy Yahya telah diejawantahkan Presiden Direktur DMID Group Daniel Surya yang diberi mandat untuk melakukan proses rebranding logo TVRI.

Dalam buku panduan identitas TVRI (2019:12) yang digarap DM-ID Group di bawah komando Presiden Direktur Daniel Surya, dituliskan, 'TVRI adalah media publik dengan integritas tinggi untuk menyuarakan berbagai nilai, budaya dan keberagaman yang menjadi kebanggaan Indonesia melalui konten programnya yang berkualitas ke seluruh lapisan masyarakat hingga ke berbagai penjuru tempat. "Karena itulah TVRI harus bisa membawa kebanggaan Indonesia dalam peradaban dunia."

Kehendak baik Direktur Utama TVRI Helmy Yahya untuk menghadirkan rebranding TVRI Pusat bersama 29 stasiun lokal TVRI di 29 kota layak didukung oleh siapa pun. Terutama penggemar dan pemirsa TVRI.
Mengapa demikian? Karena pemikiran orang nomor satu di kantor pusat lembaga penyiaran TVRI ini berdasarkan realitas sosial yang sedang berkembang di kalangan masyarakat Indonesia. Direktur Utama TVRI Helmy Yahya sangat yakin keberadaan TVRI pada era budaya layar ini menjadi tempat merepresentasikan jejak peradaban bangsa Indonesia.

Catatan verbal dan goresan visual jejak peradaban bangsa Indonesia yang direkam dan diproduksi oleh TVRI Pusat bersama 29 stasiun lokal TVRI dipercaya mampu menjadi jejak digital peradaban bangsa Indonesia. Keberadaanya menjadi sumbangan sekaligus sumber inspirasi bagi generasi milenial.

Ketika TVRI Pusat bersama 29 stasiun lokal TVRI yang tersebar di 29 kota melakukan upaya rebranding yang menurut Kamus Brand merupakan sebentuk kegiatan komunikasi visual yang terintegrasi dan terencana guna mengubah posisi sebuah brand secara internal dan eksternal (2008:116), keberadaannya diharapkan mampu menyuarakan berbagai nilai kebaikan, kebudayaan dan kearifan lokal serta keberagaman adat istiadat masyarakat Indonesia. Program tontonan dan tuntunan yang diproduksi TVRI harus dapat menjadi kebanggaan bangsa Indonesia.

Dalam konteks rebranding, suka tidak suka, TVRI Pusat bersama 29 stasiun lokal TVRI di 29 kota menjadi bagian dari pergerakan budaya visual. Yasraf Amir Piliang (2018:77) dalam bukunya Teori Budaya Kontemporer: Penjelajahan Tanda dan Makna menyebut budaya visual sebagai hasil sebuah kebudayaan yang didominasi citra visual dan visualisasi. Dengan demikian, keberadaan TVRI dalam konteks budaya visual sudah menjadi bagian dari hidup dan kehidupan masyarakat dunia.

Para pengikut budaya visual ditandai dengan aktivitasnya yang senantiasa bersinggungan dengan layar televisi, komputer dan telepon pintar yang terhubung dengan jaringan internet. Ketika bekerja mencari nafkah, layar komputer, telpon pintar berikut koneksi internet menjadi kebutuhan mutlak yang tidak bisa dipisahkan selama 8 jam di kantornya. Begitu juga layar televisi dan layar telepon genggam selalu stand by 24 jam penuh di sampingnya. Dengan demikian dapat dikatakan, keberadaan budaya visual berhasil membangun ruang publik baru dan komunitas maya baru dengan memanfaatkan piranti elektronik.

Perkembangan budaya visual dinilai sukses mewadahi masyarakat 'virtual' modern. Mereka sejatinya sangat haus melakukan interaksi sosial secara realistis dengan sesamanya. Sayangnya, hal itu tidak bisa direalisasikan karena mereka terjebak deadline dan rutinitas administrasi yang membelenggu pekerjaannya.

Selain itu, kebutuhan manusia 'virtual' modern itu semakin hari kian membutuhkan ruang dan waktu. Ruang 
adalah media untuk melakukan komunikasi dengan siapa pun. Sedang pada unsur waktu, setiap individu senantiasa membutuhkan tontonan, tuntunan, hiburan dan informasi produk barang dan jasa dengan cepat dan efisen. Maka keberadaan budaya visual dengan dukungan peralatan berbasis layar elektronik dan internet mendapatkan tempat terhormat bagi pengikutnya.

Karena budaya visual senantiasa memfasilitasi ruang dan waktu yang dibutuhkan manusia 'virtual' modern guna mengumandangkan eksistensinya. Maka budaya visual menyediakan kesempatan bagi setiap individu untuk melakukan hal itu. Budaya visual menyerahkan dirinya menjadi sarana merepresentasikan realitas diri pribadi follower-nya melalui piranti layar elektronik dan internet.

Pada titik inilah, fenomena sosial merebaknya budaya visual menimbulkan kontradiksi sekaligus memunculkan paradoks yang tidak dapat dihindarkan antara satu dengan lainnya. Dan hal ini menjadi gejala alamiah dalam jagat virtual kehidupan masyarakat 'virtual' modern.

Kambing hitam atas merebaknya fenomena sosial yang bersifat kontradiksi sekaligus paradoks salah satunya dialamatkan kepada layar televisi. Pada titik ini, sudah menjadi rahasia umum manakala layar televisi menjadi virus yang mampu menyebarkan 'kejelekan' sekaligus 'kebaikan' dalam waktu bersamaan.

Televisi telah menjadi 'orang tua baru' bagi anak-anak yang ditinggal seharian oleh orang tuanya demi mencari sesuap nasi. Sementara layar televisi bagi remaja dan orang dewasa bagaikan buku pelajaran yang mengajarkan budaya hedonis dan konsumtif dalam menapaki kehidupan modern ini. Dalam layar televisi hadir tukang sulap yang mampu menyihir penonton. Mereka membimbing penonton agar mengganti gaya hidup tradisional dengan gaya hidup modern.

Pendidikan ala layar televisi mengajarkan bagaimana cara berpikir, berbicara, berdebat, berkelahi, menyerang dan menciptakan budaya visual baru. Mereka juga dilatih untuk mengedepankan pertimbangan emosional dalam konteks memenuhi kebutuhan konsumsi. Hasil dari pendidikan layar televisi dapat disimak berupa perilaku konsumtif. Ditengarai, mereka membeli produk barang dan jasa melebihi apa yang dibutuhkan. Bahkan cenderung berlebihan.

Di dalam layar kaca didendangkan pula sebuah dogma baru: kekayaan duniawi harus diburu. Sebab kehormatan dan keberhasilan seseorang ditakar dengan seberapa banyak uang yang dimilikinya. Artinya, kuasa uang menjadi penanda kasta sosial seseorang di tengah gejolak zaman yang semakin anomali ini. Dampaknya, manusia menjadi semakin egois di dalam mempertahankan hidupnya. Segala jalan ditempuh demi mendapatkan segenggam kehor- matan duniawi.

Dahsyatnya, ajaran semacam itu mendapatkan persemaiannya yang subur di dalam ladang hati, sikap dan gaya hidup sebagian besar masyarakat Indonesia yang mengaku modern. Semuanya itu semakin menegaskan keterpurukan kita sebagai masyarakat yang miskin imajinasi. Sekumpulan besar individu yang cenderung menisbikan keselarasan nalar perasaan dan akal pikiran.

Maka tidaklah berlebihan manakala kita mengharapkan TVRI lewat upaya rebranding mampu menghidupkan imajinasi kreatif rakyat Indonesia. Program tontonan dan tuntunan yang diproduksi TVRI harus dapat menjadi kebanggaan bangsa Indonesia. Hal ini perlu menjadi prioritas pihak TVRI. Mengapa? Karena sebagian besar masyarakat Indonesia sedang terserang sindrom mati rasa perasaannya akibat terpaan gendam visual perikehidupan semu yang ditayangkan lewat layar televisi. Upaya rebranding TVRI diharapkan dapat menghidupkan dan mengembangkan aspek moralitas, kreativitas dan budi pekerti dalam payung kearifan lokal.

Berdasarkan hal tersebut di atas, tulisan berjudul Makna Konotasi Rebranding Logo TVRI dibuat dengan tujuan utama untuk memahami makna konotasi atas keberadaan tanda serta pesan komunikasi visual yang muncul dalam rebranding logo TVRI.

Tulisan ini khusus dibuat guna memahami makna konotasi pada rebranding logo TVRI dengan mengambil objek pembahasan berupa desain logo TVRI yang diluncur di hadapan masyarakat luas pada Jumat malam 29 Maret 2019, di Auditorium TVRI, Senayan, Jakarta.

Tulisan berjudul Makna Konotasi Rebranding Logo TVRI dibuat menggunakan metode penelitian kualitatif dengan mendeskripsikan dan menginterpretasikan makna konotasi rebranding logo TVRI berdasarkan bangunan teori semiotika (Barthes, 2010), (Danesi, 2010), (Eco, 1979), (Judith, 1984) (Noth, 1995), teori desain komunikasi visual (Tinarbuko, 2015), (Tinarbuko, 2017), teori branding (Aaker, 2015). Metode analisis semiotika komunikasi visual dimanfaatkan sebagai metode analisis tanda verbal dan tanda visual serta pesan verbal dan pesan visual. Proses analisis objek penelitian dilakukan dengan memanfaatkan konsep analisis Triadik Sumbo Tinarbuko (Tinarbuko, 2017).

Hasil tulisan ini diharapkan dapat memberikan kontribusi positif berupa rujukan secara teoretis kepada produsen tanda yang terdiri dari desainer komunikasi visual. Hal itu menjadi sangat penting, sebab dengan mempelajari dan menerapkan teori semiotika komunikasi visual, para produsen tanda dapat memahami tanda dan makna konotasi yang terkandung di dalam rebranding logo TVRI. Harapan lainnya, produsen tanda akan lebih kreatif dalam menciptakan tanda verbal dan tanda visual. Begitu pula saat 
merancang pesan verbal dan pesan visual yang diterapkan dalam desain logo sebagai ujung tombak proses branding produk barang dan jasa.

\section{METODE PENELITIAN}

Metode analisis semiotika komunikasi visual pada tanda verbal dan tanda visual karya desain komunikasi visual berwujud rebranding logo TVRI, sejatinya beroperasi pada dua jenjang analisis. Pertama, analisis tanda secara individual, mencakup: tanda, kode, dan makna. Kedua, analisis tanda yang membentuk teks. Sedangkan teks menurut Yasraf Amir Piliang (1998:88) dipahami sebagai kombinasi tanda-tanda. Dengan demikian, karya desain komunikasi visual salah satunya berbentuk rebranding logo TVRI dapat diposisikan sebagai sebuah teks.

Tulisan ini menggunakan metode penelitian kualitatif dengan cara mengidentifikasikan dan menginterpretasikan makna konotasi rebranding logo TVRI. Semuanya dilakukan dengan menyandarkan diri pada bangunan teori semiotika, teori desain komunikasi visual dan teori branding. Cara melakukan proses analisis objek penelitian dilakukan secara deskriptif dengan memanfaatkan konsep Triadik Sumbo Tinarbuko.

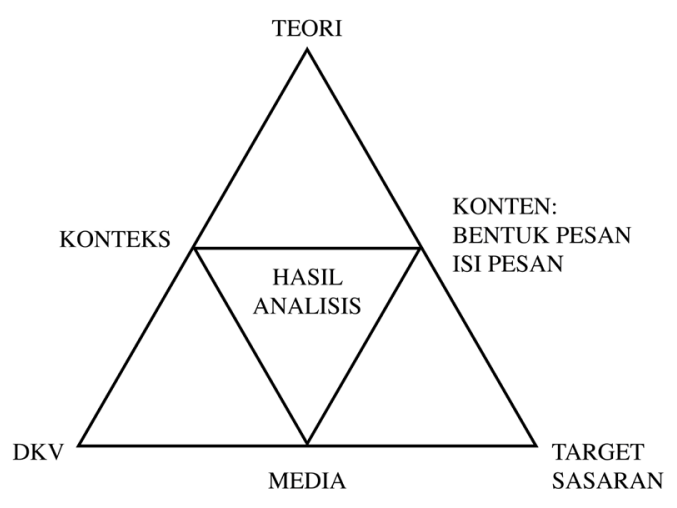

\section{TRIADIK SUMBO TINARBUKO}

Konsep ini penulis ciptakan untuk mengidentifikasikan dan memahami makna konotasi atas tanda dan pesan pada karya desain komunikasi visual berwujud rebranding logo TVRI.

Di sisi lain, rebranding logo TVRI membutuhkan media untuk merepresentasikan pesan verbal dan pesan visual yang ada di dalamnya. Untuk itu, dipilihlah media berupa desain logo.

Keberadaan rebranding logo TVRI, diselaraskan dengan target khalayak sasaran yang dituju. Garis lurus antara karya desain komunikasi visual (DKV) berbentuk rebranding logo TVRI dengan pilihan media berwujud desain logotype, penempatannya selajur dengan sudut target khalayak sasaran. Ketiganya ditempatkan pada sisi bawah garis Triadik Sumbo Tinarbuko.

Di sisi kiri Triadik Sumbo Tinarbuko terdapat sudut lurus karya desain komunikasi visual berbentuk rebranding logo TVRI adalah konteks (kesepakatan proses mengkaji karya rebranding logo TVRI, dalam bentuk rumusan masalah). Dan sudut paling atas adalah teori utama dan teori penunjang yang digunakan sebagai referensi untuk membantu mengkaji objek pembahasan tersebut.

Di sisi sebelah kanan garis Triadik Sumbo Tinarbuko dimulai dari sudut target khalayak sasaran, lalu naik ke sudut konten (berisi bentuk pesan dan isi pesan rebranding logo TVRI) dan di sudut atas ketemu lagi dengan sudut puncak yang berisi teori utama dan teori penunjang yang digunakan sebagai referensi untuk membantu mengkaji objek pembahasan makna konotasi rebranding logo TVRI.

Singgungan antara sisi kiri garis Triadik Sumbo Tinarbuko bernama konteks akan terhubung garis lurus dengan singgungan sisi kanan bernama konten. Selanjutnya menurun menghubungkan sudut lain hasil dari singgungan karya desain komunikasi visual berwujud rebranding logo TVRI, dengan khalayak sasaran yang bernama media. Ketiga titik tersebut (konteks - konten - media) membentuk segitiga sama sisi terbalik. Pada titik itulah alur pikir kajian semiotika komunikasi visual menemukan bentuknya berupa paparan deskrisptif makna konotasi tanda verbal dan tanda visual serta pesan verbal dan pesan visual rebranding logo TVRI yang menjadi objek pembahasan tulisan ini (Tinarbuko, 2017:55-56).

\section{ANALISIS DAN INTERPRETASI DATA}

\section{Identifikasi dan Deskripsi Desain Logo TVRI}

\section{Tanda Verbal dan Pesan Komunikasi Visual Logo TVRI}

Buku Panduan Identitas TVRI (2019:12-18) yang digarap DM-ID Group di bawah komando Presiden Direktur Daniel Surya menyebutkan konsep dasar diciptakannya logo baru TVRI pemikiran bahwa TVRI adalah media publik dengan integritas tinggi untuk menyuarakan berbagai nilai, budaya, dan keberagaman yang menjadi kebanggaan Indonesia melalui konten programnya yang berkualitas ke seluruh lapisan masyarakat hingga ke berbagai penjuru tempat (2019:12). Untuk itu, keberadaan lembaga penyiaran TVRI harus bisa membawa kebanggaan Indonesia ke mata dunia. Selain itu, TVRI diposisikan menjadi media yang Multimedia, Multiplatform, dan Multicanal. Dapat dipercaya oleh publik. Tidak tergantung oleh pemerintah (2019:13). Terpenting, TVRI harus menjadi media layanan publik Indonesia yang terintegrasi di berbagai platform dengan hiburan yang mengangkat nilai, kebudayaan, dan keberagaman yang membanggakan Indonesia (2019:14). 
Karena TVRI diposisikan menjadi media layanan publik Indonesia yang terintegrasi di berbagai platform dengan hiburan yang mengangkat nilai, kebudayaan, dan keberagaman yang membanggakan Indonesia, maka diusunglah konsep APIK (2019:16-18) sebagai representasi rebranding logo TVRI.

APIK yang terdiri dari diksi Adaptif, Positif, Informatif, Kreatif. Jabaran sebagai berikut: Adaptif. TVRI mampu beradaptasi dengan kebutuhan audiensnya dalam berbagai touchpoint karena selalu mengikuti perkembangan zaman. Ciri utamanya direpresentasikan dalam diksi Dinamis dan Relevan.

Positif. TVRI berintegritas untuk menyebarkan berita yang netral dan dapat membangun persatuan. Ciri utamanya direpresentasikan dalam diksi Bersemangat dan Ramah.

Informatif. TVRI tidak hanya memberikan konten dan program yang menghibur, namun juga bisa memberikan nilai edukasi. Ciri utamanya direpresentasikan dalam diksi Meyakinkan dan Berwawasan.

Kreatif. TVRI mampu berinovasi melalui berbagai cara agar bisa memberikan pengalaman baru untuk audiensnya. Ciri utamanya direpresentasikan dalam diksi Menghibur dan Inovatif.

\section{Tanda Visual dan Pesan Komunikasi Visual Logo TVRI}

Warna rebranding logo TVRI dipilih warna Trusted Blue. Menurut Buku Identitas TVRI, warna biru dipilih sebagai simbol lautan Indonesia yang penuh kekayaan. Warna biru dianggap menjadi warna yang tepat untuk menitikberatkan potensi TVRI sebagai sumber referensi terpercaya dan media pemersatu bangsa di masa depan.

Secara visual logo TVRI memanfaatkan lingkaran biru yang menjadi dasar atau alas untuk meletakan huruf "'RI'. Berdasarkan catatan yang tertera di dalam Buku Identitas TVRI, Lingkaran Biru divisualkan sebagai simbol penyambung dunia. TVRI hadir dalam satu siaran, satu suara, satu Indonesia untuk dunia.

Tipografi menggunakan jenis font Avenir Next dan Gotham. Sedangkan tagline: TVRI Media Pemersatu Bangsa

\section{Analisis Semiotika Komunikasi Visual pada Rebrand- ing Logo TVRI}

Program rebranding TVRI dilakukan untuk mengenalkan serta menunjukkan keberadaan jejak peradaban bangsa Indonesia. Hal ini perlu digarisbawahi karena pada era peradaban digital sekarang ini brand diposisikan dan direkatkan makna konotasi sebagai panglima perang yang merepresentasikan garis perjuangan dan jatidiri dari lem- baga penyiaran TVRI.

Atas dasar itulah disodorkan konsep baru yang mendekonstruksi brand bukan kembaran dari merek. Sebab brand adalah merek plus-plus. Keberadaannya meliputi segenap jiwa raga dari sang manusia itu sendiri. Brand harus dijaga dalam posisi sebagai kata kerja. Bukan kembali pada posisi asal, yakni tetap menjadi kata benda.

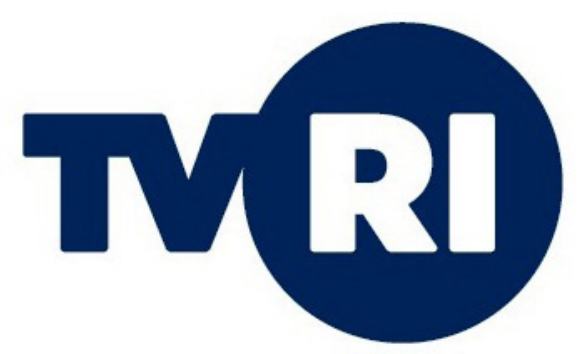

Desain logo TVRI dikerjakan DM-ID Group Jakarta di bawah komando Presiden Direktur Daniel Surya

Desain logo TVRI secara terdiri dari empat huruf: $\mathrm{T}-\mathrm{V}$ - R - I. Huruf ' $T$ ' dan ' $V$ ' disandingkan menjadi satu dan dibaca teve. Diksi teve secara semiotika dimaknai sebagai kepanjangan dari televisi. Sebuah kotak ajaib yang dapat yang mampu memancarkan pesan komunikasi visual dalam pancaran frekuensi UHF analog dan UHF digital. Di dalam televisi penonton dapat menyaksikan berbagai mata acara yang ditayangkan dalam bentuk jurnalistik televisi: berupa warta berita. Ada juga tayangan televisi bersifat nonberita. Di antaranya tayangan hiburan sinetron, film, pertunjukan musik, kuis, siaran olahraga, talkshow.

Sementara itu, huruf ' $R$ ' dan huruf 'I' direkatkan sedemikian rupa. Kedua huruf itu, secara semiotika dimaknai sebagai kepanjangan dari Republik Indonesia. Sebuah identitas nama negara Republik Indonesia dengan ibukota Jakarta. Kata Republik Indonesia menjadi penanda visual yang memiliki makna konotasi: lembaga penyiaran TVRI adalah perusahaan umum milik negara Republik Indonesia. Biaya operasionalnya menggunakan uang negara yang dipungut dari iuran pajak.

Sebagai lembaga penyiaran plat merah, TVRI mengemban tugas negara sebagai media pemersatu bangsa. Makna konotasi yang muncul, TVRI wajib menayangkan siaran mata acara yang bersifat berita atau pun non berita dengan satu tujuan utama mewujudkan dan menjalankan amanat sila ketiga Pancasila. TVRI memiliki tugas Negara mengedukasi penontonnya untuk senantiasa menjalankan tugas sosial guna mewujudkan persatuan Indonesia. Sebuah sikap hidup berbangsa dan bernegara yang mengedepankan kerja kolaborasi untuk saling melindungi dan menghormati kemerdekaan hidup warga masyarakat. Bersikap rela menerima atas berbagai perbedaan dan keberagaman antar sesama warga. 
Bentuk geometris berupa ikon lingkaran biru Trusted Blue yang diposisikan menjadi dasar untuk meletakkan simbol huruf "RI" berwarna putih mengandung makna konotasi sebagai representasi simbol persatuan dan kebersamaan seperti yang diamanatkan sila ketiga dari Pancasila: Persatuan Indonesia.

Warna biru Trusted Blue pada ikon lingkaran yang melingkupi huruf ' $\mathrm{RI}$ ” juga memiliki makna konotasi yang merepresentasikan lembaga penyiaran TVRI sebagai media massa elektronik yang memproduksi tayangan visual yang terpercaya, menghibur sekaligus mendidik penonton Indonesia untuk senantiasa mewujudkan sila ketiga dari Pancasila, yakni Persatuan Indonesia.

Makna konotasi lainnya dari ikon lingkaran berwarna biru Trusted Blue, TVRI sebagai lembaga penyiaran milik pemerintah harus menjadi media massa elektronik yang mampu menjadi jembatan komunikasi visual yang menyambungkan informasi yang ada di Indonesia dan informasi yang muncul dari belahan dunia lain di luar jagat raya Indonesia.

Ketika simbol huruf "TV" dan ikon lingkaran biru Trusted Blue direkatkan sedemikian rupa, secara semiotika komunikasi visual, hal ini memunculkan makna konotasi yang cukup menarik. Kedekatan simbol huruf " $\mathrm{T}$ ", simbol huruf "V" dan ikon lingkaran biru secara konotatif dapat dipahami sebagai sebuah upaya dari lembaga penyiaran TVRI untuk menjadi media bersifat multimedia, multiplatform dan multicanal. Penanda visual semacam itu mendorong TVRI untuk memiliki etos kerja profesional. Menjadi kebanggaan rakyat, bangsa dan Negara Indonesia karena sajian konten mata acara yang terpercaya, beragam, netral, unik, menghibur, mendidik dan komunikatif.

Pilihan tipografi dengan memilih dan menggunakan jenis font Avenir Next dan Gotham secara semiotika memiliki makna konotasi netral dan tegas, namun bersahabat. Hal ini selaras dengan keberadaan TVRI yang senantiasa menjalin kerja kolaborasi dengan berbagai pihak. Senantiasa memproduksi dan menyiarkan warta berita tayangan non berita yang terpercaya, netral, menghibur dan mendidik. Semuanya itu dikerucutkan demi membangun kehidupan berbangsa dan bernegara dengan mengedepankan ideologi persatuan Indonesia.

Manakala dicermati keberadaan rebranding logo TVRI dengan penanda visual simbol huruf "TV" dan ikon lingkaran berwarna biru yang di dalamnya ditempelkan simbol huruf "RI", maka dari situ dapat dipahami makna konotasi yang terkandung di dalamnya. Makna konotasi itu terlihat daru upaya TVRI untuk senantiasa menjalin kerja kolaborasi kreatif dengan penontonnya. TVRI mengedepankan kerja cerdas yang dilandasi pada sikap profesionalitas dengan menayangkan berita dengan sumber akurat dan seimbang. TVRI memproduksi tayangan non berita yang bersifat menghibur sekaligus mendidik.

Pada akhirnya, rebranding logo TVRI dihadirkan untuk merepresentasikan kualitas nilai produk tayangan TVRI. Kehadirannya secara konotatif dimaknai sebagai upaya untuk menghadirkan unsur pembeda signifikan antara brand lembaga penyiaran milik negara dengan lembaga penyiaran milik swasta.

\section{SIMPULAN}

Tulisan ini dibuat untuk melakukan proses pengkajian semiotika komunikasi visual pada karya desain komunikasi visual berwujud rebranding logo TVRI. Proses pengkajian diawali dengan melakukan tahapan identifikasi dan deskripsi atas tanda dan pesan komunikasi visual yang ada di dalam rebranding logo TVRI. Proses pengkajian berikutnya dilakukan dengan mencari, menemukan serta memahami makna konotasi atas keberadaan pesan komunikasi visual yang terkandung di dalam rebranding logo TVRI.

Penerapan analisis semiotika komunikasi visual dengan memanfaatkan konsep analisis Triadik Sumbo Tinarbuko pada objek pembahasan rebranding logo TVRI ini, melibatkan penggunaan bangunan teori semiotika, teori desain komunikasi visual dan teori branding. Semua unsur semiotika yang meliputi tanda dan makna menjadi pertimbangan utama dalam melihat dan menangkap pesan komunikasi visual rebranding logo TVRI. Penerapan analisis semiotika komunikasi visual diharapkan mampu menjadi salah satu pendekatan baru untuk memahami makna konotasi atas keberadaan karya desain komunikasi visual berwujud rebranding logo TVRI.

Secara konotatif, pesan komunikasi visual yang terkandung di dalam program rebranding logo TVRI memiliki kekuatan yang bersifat humanis. Agar modal sosial dari program rebranding logo TVRI menjadi realitas sosial perlu dibuat kesepakatan baru antar para pihak. Mengapa demikian, sebab pada dasarnya, sebuah brand, dalam konteks branding lembaga penyiaran TVRI, keberadaannya tidak sekadar membuat serta merancang nama dan desain brand saja. Kemudian diparafrasekan dan divisualkan dengan pendekatan desain komunikasi visual agar menjadi sebuah desain logo lengkap dengan identitas visualnya.

Untuk itu harus disadari oleh siapa pun bahwa sejatinya brand tidak sama dengan merek. Ibarat raga manusia, merek sekadar nama pribadi manusia. Ketika pendapat umum masih menganggap brand identik dengan merek. Realitas sosial yang muncul, brand tersebut senantiasa berjarak dengan objek yang diberi nama atau merek. 


\section{DAFTAR RUJUKAN}

Aaker, David. (2014 ). Aaker On Branding, terjemahan Eta Sitepoe (2015). Jakarta: Penerbit PT Gramedia Pustaka Utama

Barthes, Roland (2010). Image/Music/Text atau Imaji Musik Teks, terjemahan Agustinus Hartono (1990). Yogyakarta: Penerbit Jalasutra.

Danesi, Marcel. (2010). Messages, Signs, and Meaning: A Basic Textbook in Semiotics and Communication Theory atau Pesan, Tanda, dan Makna: Buku Teks Dasar Mengenai Semiotika dan Teori Komunikasi, terjemahan Evi Setyarini dan Lusi Lian Piantari (2004). Yogyakarta: Penerbit Jalasutra.

Eco, Umberto. (1979). A Theory of Semiotics. Bloomington: Indiana University Press.

MPR RI. (2018). Materi Sosialisasi Empat Pilar MPR RI. Jakarta: Sekretariat Jendral MPR RI.

Noth, Winfriend. (1995). Handbook of Semiotics. Blommington and Indianapolis: Indiana University Press.

Piliang, Yasraf Amir. (1998). Sebuah Dunia yang Dilipat, Realitas Kebudayaan menjelang Milenium Ketiga dan Matinya Posmodernisme. Bandung: Penerbit Mizan.

Piliang, Yasraf Amir. (2018) Teori Budaya Kontemporer: Penjelajahan Tanda dan Makna. Yogyakarta: Penerbit Cantrik Pustaka.

Tinarbuko, Sumbo. (2009). Semiotika Komunikasi Visual (Edisi Revisi). Yogyakarta: Penerbit Jalasutra.

Tinarbuko, Sumbo. (2015). DEKAVE: Desain Komunikasi Visual Penanda Zaman Masyarakat Global. Yogyakarta: Penerbit CAPS.

Tinarbuko, Sumbo. (2017). Membaca Tanda dan Makna Desain Komunikasi Visual. Yogyakarta: Penerbit BP ISI Yogyakarta.

TVRI. (2019). Buku Panduan Identitas. Jakarta: DM-ID Group

Williamson, Judith. (1984). Decoding Advertisements, Ideology and Meaning in Advertising. London: Marion Boyars Publishers Ltd, 24 Lacy Road.

Wiryawan, Mendiola B. (2008). Kamus Brand. Jakarta: Red \& White Publishing.

\section{Webtografi}

https://kumparan.com/sumbo-tinarbuko/rebranding-tvri-era-budaya-digital-1554311575882828073

https://mediaindonesia.com/read/detail/226523-ganti-logo-tvri-cerminkan-budaya-dan-semangat-baru

h t t p s : / / e k b i s . h a r i a n j o g j a . c o m / $\mathrm{read} / 2019 / 04 / 02 / 502 / 982342 /$ tvri-siap-bersaing-di-dunia-internasional 